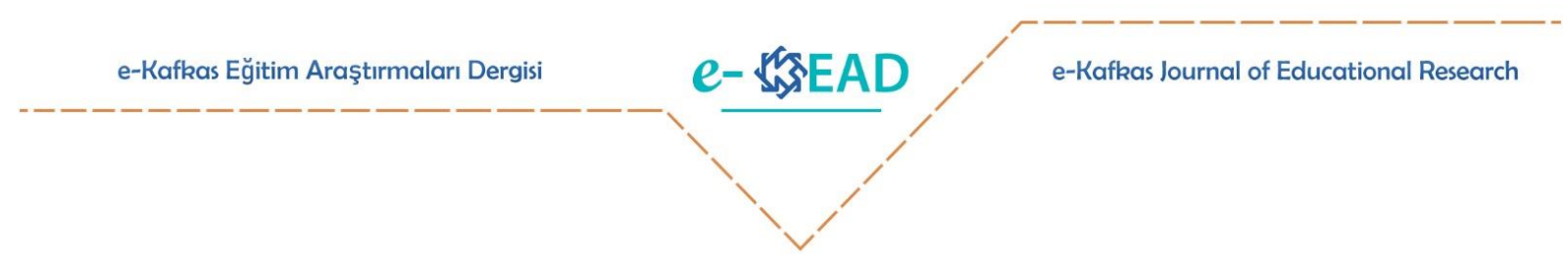

\title{
Bilim Şenliklerinin Öğrencilerin Fen Dersleri ve Proje Ödevlerine Yönelik Tutumlarına Etkisinin Belirlenmesi*
}

\author{
Identifying the Effects of Science Festivals on Students' Attitudes towards Science \\ Courses and Projects
}

Emirhan KESKİN $₫$ Zafer KARAGÖLGE 10 İlhami CEYHUN $₫$

Atıf: Keskin E., Karagölge Z. ve Ceyhun İ. (2019). Bilim şenliklerinin öğrencilerin fen dersleri ve proje ödevlerine yönelik tutumlarına etkisinin belirlenmesi. e-Kafkas Ĕ̆itim Araştırmaları Dergisi, 6(3), 1-12.

Araştırma Makalesi Geliş Tarihi: 25.07.2019 Kabul Tarihi: 15.12.2019

Doi: 10.30900/kafkasegt.596585

$\ddot{O} \mathbf{z}$

$\mathrm{Bu}$ çalışmada, bilim şenlikleri ile öğrencilerin özelde kimya genelde fen (fizik, kimya, biyoloji) derslerine yönelik olumlu tutum geliştirmelerini sağlamak ve bilim şenliğinde aktif görev alan öğrencilerin proje ödevleri hakkındaki görüşlerini almak amaçlanmıştır. Araştırma 2016-2017 eğitim öğretim yılı 2. döneminde Erzurum ili Horasan ilçesinde bulunan Horasan Anadolu Lisesi'ndeki öğrencilere uygulanmıştır. Fen derslerindeki tutumların değişimini ölçmek için tek grup ilk test son test desen, bilim şenliğinde aktif görev alan öğrencilerin proje ödevleri hakkındaki görüşlerini almak için ise betimsel yöntem kullanılmıştır. Bulgular incelendiğinde bilim şenlikleri ile öğrencilerin fen derslerine yönelik tutumlarının olumlu yönde arttı̆̆ görülmüştür. Ayrıca proje ödevi alan öğrencilerin proje ödevlerini bilim şenliği şeklinde sunmaya sıcak baktıkları ve daha hevesli oldukları görülmüştür. Bilim şenliklerinin öğrencilerin fen derslerine ve proje ödevlerine yönelik tutum düzeyleri üzerindeki olumlu etkisi göz önüne alındığında, ülkemizdeki okullarda bilim şenlikleri gibi etkinliklerin yaygınlaştırılması ve öğrencilerin bu tür etkinliklere katılımlarının teşvik edilmesinin yararlı olacağı düşünülmektedir.

Anahtar Sözcükler: Bilim şenliği, fen bilimleri, kimya eğitimi, proje ödevi, öğrenci tutumları

\section{Abstract}

This study aims to help students develop positive attitudes towards science courses through science festivals as well as receiving opinions of those who have taken part actively in science festival projects. This study has been applied to Horasan Anatolian High School students located in Erzurum, Horasan in the 2nd term of 2016-2017 academic year. In order to measure the changes in the attitudes of students in science courses, one group pretest-posttest experimental design was used, while the case study method was applied to receive opinions from students, who have actively taken part in the science festival projects. When findings are analyzed, it is observed that the attitudes of science festival students have positively changed towards science courses. Also, it is recorded that students who took their project assignments in science courses are more willing to present their projects in the form of science festivals. Bearing in mind the positive impact of science festivals on students' success and attitudes in science classes, it is surmised that it would be educationally beneficial if science festivals were popularized throughout our country and students were encouraged to participate in such activities.

Keywords: Science fair, science, chemistry education, project assignment, student attitudes

\footnotetext{
* Bu çalı̧̧ma yazarların 18-22 Nisan 2018 tarihinde Antalya'da düzenlenen ICES-UEBK 27. Uluslararası Eğitim Bilimleri Kongresi'nde sundukları 'Bilim Şenliklerinin Öğrencilerin Fen Derslerine ve Proje Ödevlerine Yönelik Tutumlarına Etkisi' başlıklı sözlü bildirisine dayalı olarak hazırlanmıştır.
} 


\section{Giriş}

Fidan (1996), eğitimi "en genel anlamıyla insanları belli amaçlara göre yetiştirme süreci" olarak tanımlamış ve bu sürece dâhil olan insanların kişiliğinin değiştiğini, bu değişimin eğitim sürecine dâhil olunması sonucu elde edilen bilgi, beceri ve tutumlar yoluyla gerçekleştiğini belirtmiştir. Eğitim sürecinden geçen bireyin amaçları, davranışları ve bilgileri değişmektedir. Eğitim sürecine giren bireyde bu değişikliklerin olumlu yönde olması gerekir (Demirel, 1999). Öğretme, hedef alınan kritik davranışların bütün öğrencilere etkili ve verimli bir şekilde kazandırılması amacıyla gerçekleştirilen her türlü etkinliği ifade eder (Aydın, 2007). Bu yönüyle öğrenme ortamının ögrencilerin sosyal etkileşim yoluyla aktif olarak katılmasına imkân sağlaması gerekmektedir (Philipps, 2010). Öğretme, öğretmen ve öğrenciler arasında karşılıklı bir ilişki ile yürür ve bu etkinliğinin verimli bir şekilde yürümesi sağlıklı bir iletişimle olmaktadır. Bu iletişim ağında verici öğretmen olduğu kadar alıcı durumundaki öğrenci de önemlidir. Öğretmen mesajı ne kadar iyi iletirse iletsin öğrenci mesaj1 alabildiği kadar öğrenir. Öğrencinin mesajı alabilmesinde duyuşsal ve bilişsel faktörler birlikte görev almaktadır. Öğrenci bilişsel olarak yeterli olsa bile duyuşsal eksiklikleri öğrencinin başarı çizgisinden sapmasına neden olmaktadır. Özgüven eksikliği, önyargı, korku, ilgisizlik, derse karşı yakınlık kuramama, inancını kaybetme, yeteneğinin farkında olamama, eğlenceli bulmama gibi faktörler örnek olarak gösterilebilir. Dolayısıyla eğitim hayatında öğrencinin başarıya ulaşması, bilişsel ve duyuşsal faktörlerin birlikteliğine bağlıdır (Yalın, 2003).

Günümüzde öğrencilerin başarısızlık sebepleri ile ilgili yayınlar da sıklıkla göze çarpmaktadır. Öğrencilerin başarısızlıklarının nedenlerini anlatan bilimsel çalışmaların yanı sıra medya da çözüm yolları sunarak eğitimcilere yardımcı olmaya çalışmaktadır. Öğrenciler günü gününe ders çalışma, not alma ve tekrar etme gibi tekniklerle akademik olarak başarılı olsalar bile; derse karşı önyargılı olma gibi duyuşsal eksikliklerini gideremeyecekledir. Öğrencinin oluşan bu olumsuz tutumu gelecek hayatına da yön verecektir (Seferoğlu, 2004). Bu nedenle öğrencinin duyuşsal sorunlarında çeşitli uygulamaların da yapılması gerekmektedir. Nitekim 2018 yılında yayınlanan öğretim programında öğrenme sürecinin öğrencilerin tutumlarını artırıcı yönde olması gerektiği belirtilmiştir (MEB, 2018).

İlköğretimden başlayarak eğitimin her kademesinde yer alan derslerde ödevlerin birçok yararı söz konusudur. Bu ödevler, öğrencilerin sorumluluk duygusuna sahip olmalarının sağlaması yanında, mevcut bilgilerini pekiştirme ve bu bilgilerden çıkarımda bulunarak yeni bilgiler üretebilme yollarını öğrenmeyi sağlayan temel öğretim tekniklerinden biridir (Kütükte, 2010). Proje ödevleri, öğrencilerin, araştırma, problem çözme, öğrendiklerini kullanma gibi üst düzey düşünme gerektiren, gerçek yaşama benzer işler üzerinde, özgün bir ürün ortaya koymak amacıyla yaptıkları çalışmadır (Aladağ, 2005). Proje ödevlerinin amaçları ile sonuçları kıyaslandığında bazı eksiklikler de hissedilmektedir. Proje ödevlerinin etkin bir şekilde uygulanması öğrencilerin öğrenmelerinde önem arz etmektedir. Özellikle proje ödevlerinin öğrencilerin gündelik yaşamları ile ilgili olmaları öğrencilerde daha etkili bir öğrenmeyi gerçekleştirebilecektir (The Physical Sciences Initiative, 1991). Bunun yanı sıra, proje ödevleri günlük durumlarla, bilimsel kavramların ilişkilendirilmesi ile öğrencilerin fen bilimlerine yönelik olumlu tutum geliştirmelerine yardımcı olmayı amaçlamaktadırlar (Barker \& Millar, 2000). Öğrenciye verilen proje ödevinde öğrenci ne kadar aktif olursa amaçlanan hedeflere ulaşmada daha iyi sonuçlar alınacaktır (Bozkurt, Aslanargun, Akın, \& Kılıç, 2014).

Günümüzde bilim ve teknoloji alanında kaydedilen ilerlemeler, ülkeler arasında hem ekonomik hem de saygınlık yönünden üstünlük kurulmasını sağlamaktadır. Bu da bilgiyi kullanabilen, eleştirel düşünen, öğrenmelerini farklı alanlara aktarabilen, problem çözme becerilerine sahip, empati yapabilen bireylerin varlığına bağlıdır (Bozdemir, 2018). Bu amaçla ülkelerin bilim ve teknoloji çalışmalarına gereken önemi vermeleri gerekmektedir. Özellikle son yıllarda eğitimde bilim şenliklerine yer verilmesi ile öğrencilerin bilim ve teknoloji okuryazarı olarak yetiştirilmeleri amaçlanmaktadır (Bacanak, Karamustafaoğlu, \& Köse, 2003; Şahin, 2012; Yıldırım \& Şensoy, 2016).

Bilim şenliği ve proje yarışmaları, öğrencilerin bilimsel araştırma sürecine uygulamalı olarak doğrudan katılmasına olanak veren, öğrenci projelerinin sunulduğu ve paylaşıldığı organizasyonlardır (Korkmaz, 2004). Son yıllarda giderek artan bilim şenlikleri etkinlikleri geniş çevre tarafindan destek bulmuştur (Tezcan \& Gülperçin, 2008). Fen eğitiminin en popüler konularından birisi de, bilim 
şenliklerinin kalıcı öğrenmelere olan etkisinin araştırılmasıdır. Birçok öğretmen bilim şenliklerinin öğrencilerin yaratıcılıklarını geliştirdiğini, kendi projelerini seçerek bağımsız araştırma yapmalarına firsat sağladığını ve bilime karşı ilgilerini artırdığını belirtmektedirler (Bunderson \& Anderson, 1996). Öğrencilerin bilim şenliklerinde bilgiyi yaşayarak öğrenmeleri, hazırladıkları etkinlikleri arkadaşları ile paylaşmaları ve öğrencilerin fen derslerine karşı özgüvenlerinin artması önem arz etmektedir. Öğrenciler bilim şenliği sayesinde sundukları ürünlerini sahiplenme duygusunu da tatmaktadırlar (Camc1, 2008). Bilim insanları bilim şenliklerinin, öğrenciler için bilim adamlarının nasıl çalıştıklarını anlamaları için etkili bir öğrenme modeli oluşturduğunu vurgulamaktadır. Bu projeler sayesinde öğrenciler, derslerde öğrenmiş oldukları teorik bilgileri uygulama olanağına sahip olmaktadırlar (Young, 2000). Bilim şenliklerinin öğrencilere birçok özelliği (iletişim kurma, işbirlikli çalışma, özgüven sağlama, planlı çalışma, kendini ifade edebilme vb.) öğretici olmasının yanında en önemli özelliği, öğrencilere bilimsel araştırma yöntemini kullanmalarını, bilime ve bilim insanına ilgilerini artırmada etkili olmasıdır (Camc1, 2008). Bilim şenlikleriyle ilgili kaynaklar incelendiğinde, ülkemizde eğitimin farklı kademelerindeki öğrencilerin bilim şenlikleri ile fen derslerine yönelik tutumlarıyla ve bilim şenliği tutum ölçeği: geçerlilik ve güvenirlikle ilgili yapılmış çalışmalara rastlanmaktadır (Şahin, 2012; Yıldırım \& Şensoy, 2016; Keçeci, Kırbağ Zengin, \& Alan, 2017). Öğrencilerin başarıları ve bilimsel inanışlar üzerine olumlu etkisini gösteren çalışmalar da bulunmaktadır (Yavuz, Büyükekşi, \& Büyükekşi, 2014;Karadeniz \& Ata, 2013). Knapp (2000), öğrencilerin bilim şenliklerinde sergiledikleri konulara karşı ilgilerinin arttığını çalışmasında gözlemlemiştir. Yıldırım'a (2018) göre ise bilim şenlikleri, öğrencilerin problem çözme becerileri düzeylerinin anlamlı seviyede arttırmaktadır. Bilim şenliklerinin yanında bilim merkezlerine yapılan ziyaretlerde öğrencilerin fen bilimleri derslerine yönelik motivasyonlarını artırdığını gösteren çalışmalar da bulunmaktadır (Çığrık, 2016). Çiçek (2008) ise bilim şenliklerinin kimya dersindeki başarı ve tutumlarına olumlu etkisinin olduğunu belirtmiştir. Bu tür çalışmaların öğrencilerin kimya bilgilerine dayanak oluşturacağını belirten Çiçek (2008), bilim şenliklerinin öğrencilerin kendilerini gösterme olanağı sağlamasıyla başarısız öğrencileri kazanma ve bilimi sevdirme yönüne de dikkat çekmiştir.

Son yıllarda eğitimde bilim şenliklerine yer verilmesi ile öğrencilerin bilim ve teknoloji okuryazarı olarak yetiştirilmeleri amaçlanmaktadır. Öğrencilerin bilim şenliklerinde bilgiyi yaşayarak öğrenmeleri, hazırladıkları etkinlikleri arkadaşları ile paylaşmaları ve öğrencilerin fen derslerine karşı özgüvenlerinin artması önem arz etmektedir. Bu yönüyle okullarımızda bu tür bilimsel etkinliklere ihtiyaç duyulmaktadır (Tübitak Proje Rehberi, 2012; Tübitak Bilim Fuarları).

$\mathrm{Bu}$ araştırmada bilim şenliklerinin 9. ve 10. sınıf öğrencilerinin özelde kimya genelde fen (fizik, kimya, biyoloji) derslerine yönelik tutumlarına etkisini ve bilim şenliğinde aktif görev alan öğrencilerin görüşlerini almak amaçlanmıştır. Araştırma kapsamında;

1. Bilim şenliklerinin 9. ve 10. sınıf öğrencilerinin özelde kimya genelde fen (fizik, kimya, biyoloji) derslerine yönelik tutumlarında olumlu etkisi var mıdır?

2. Bilim şenliğinde aktif görev alan öğrencilerin proje ödevleri hakkındaki görüşleri nelerdir? sorularına cevap aranacaktır.

\section{Yöntem}

$\mathrm{Bu}$ araştırmada, bilim şenliklerinin 9. ve 10. sınıf öğrencilerinin özelde kimya genelde fen (fizik, kimya, biyoloji) derslerine yönelik tutumlarına etkisini ölçmek amacıyla tek grup ilk test son test desen, bilim şenliğinde aktif görev alan öğrencilerin proje ödevleri hakkındaki görüşlerini ölçmek amacıyla betimsel yöntem yapılmıştır.

\section{Çalışma Grubu}

Araştırma, 2016-2017 eğitim öğretim yılı 2. döneminde Erzurum ili Horasan ilçesinde bulunan Horasan Anadolu Lisesi'nde uygulanmıştır.

$\mathrm{Bu}$ araştırmada iki tür çalışma grubu bulunmaktadır. Bunlardan birincisi, bilim şenliklerinin özelde kimya genelde fen (fizik, kimya, biyoloji) derslerine yönelik tutumlara etkisini ölçmek amacıyla oluşturulan çalışma grubudur. İkinci çalı̧̧ma grubu ise bilim şenliğinde aktif olarak görev 
alıp, proje ödevleri hakkında görüşleri incelemek amacıyla oluşturulan çalışma grubudur. Araştırmada bilim şenliklerinin 9. ve 10. sinıf öğrencilerinin özelde kimya genelde fen (fizik, kimya, biyoloji) derslerine yönelik tutumlarına etkisini ölçmek amacıyla 9. ve 10. sınıflarda öğrenim gören 256 öğrencinin tamamı birinci çalışma grubunu oluşturmuştur. Bilim şenliğinde aktif görev alan öğrencilerin proje ödevleri hakkındaki görüşlerini ölçmek amacıyla 9, 10, 11 ve 12. sinıflarda öğrenim gören proje ödevi almış 27 öğrenci ise ikinci çalışma grubunu oluşturmuştur. Tablo 1 ve Tablo 2'de çalışma grupları hakkında bazı bilgiler verilmiştir.

Tablo 1. Bilim şenliklerinin Fen Derslerine Yönelik Tutumlara Etkisini Ölçmek Amacıyla Oluşturulan Çalışma Grubunun Özellikleri

\begin{tabular}{lcc}
\hline Değişkenler & 9. Sinıf & 10. Sinıf \\
\hline Kiz & 77 & 84 \\
\hline Erkek & 44 & 51 \\
\hline Toplam & 121 & 135 \\
\hline
\end{tabular}

Tablo 2. Bilim Şenliğinde Aktif Görev Alan Öğrencilerin Proje Ödevleri Hakkındaki Görüşlerini İncelemek Amacıyla Oluşturulan Çalışma Grubunun Özellikleri

\begin{tabular}{lcccc}
\hline Değişkenler & 9. Sinıf & 10. Sinıf & 10. Sınıf & 11. Sinıf \\
\hline Kız & 6 & 9 & 6 & 1 \\
\hline Erkek & 0 & 1 & 2 & 2 \\
\hline Toplam & 6 & 10 & 8 & 3 \\
\hline
\end{tabular}

\section{Veri Toplama Araçları}

Araştırmada veri toplama aracı olarak Fen Derslerine Yönelik Tutum Ölçeği (FDYTÖ) ve Proje Ödevlerine Yönelik Tutum Ölçeği (PÖYTÖ) kullanılmıştır.

Fen Derslerine Yönelik Tutum Ölçeği (FDYTÖ): Bilim şenliklerinin öğrencilerin fen derslerine yönelik tutumlarına etkisini ölçmek amacıyla araştırmacı tarafından hazırlanan tutum ölçeğidir. Ölçek beşli likert tipinde olup 10 maddeden oluşmaktadır. Ölçekte öğrencilerin düşüncelerini, 'Kesinlikle Katılmıyorum', 'Katılmıyorum', 'Kararsızım', 'Katılıyorum', 'Kesinlikle Katılıyorum' şeklinde yansıtmaları istenmiştir. İçerik ve kapsam geçerliliği uzman görüşleri alınarak gerekli düzeltmeler yapılmış ve test uygulamaya hazır hale getirilmiştir.

Proje Ödevlerine Yönelik Tutum Ölçeği (PÖYTÖ): Bilim şenliklerinde aktif olarak görev alan öğrencilerin proje ödevlerine yönelik görüşlerini almak amacıyla araştırmacı tarafından hazırlanan tutum ölçeğidir. Ölçek beşli likert tipinde olup 10 maddeden oluşmaktadır. Ölçekte öğrencilerin düşüncelerini 'Kesinlikle Katılmıyorum', 'Katılmıyorum', 'Kararsızım', 'Katılıyorum', 'Kesinlikle Katılıyorum' şeklinde yansıtmaları istenmiştir. İçerik ve kapsam geçerliliği uzman görüşleri alınarak gerekli düzeltmeler yapılmış ve test uygulamaya hazır hale getirilmiştir.

\section{Veri Toplama Süreci}

Araştırma 7 aylık bir süreçte gerçekleştirilmiştir. Araştırmaya görev alan öğrenciler ile birlikte çalışma başlıklarının seçilmesiyle başlanmıştır. Öğrencilerin görsel kaynakları, maketleri, anket sorularını ve deney başlıklarını araştırmaları için yeterli süre verilmiş, ileri bir takvimde fikir alışverişleri yapılıp konu başlıkları belirlenmiştir. Konu başlıkları belirlendikten sonra öğrencilere görev paylaşımı yapılmış, çalışmalar için gerekli araç ve gereçlerin temini sağlanmıştır. Öğrencilere görev aldıkları alanda serbest çalışabilme ve özgün ürün ortaya koyma imkânları verilmiştir. Bilim şenliği sergi alanı belirlendikten sonra öğrenciler, ürünlerini hazırlayıp sunuma hazır hale getirmişlerdir.

Bilim şenliği belirlenen tarihte sunum alanında başarılı bir şekilde gerçekleştirilmiştir. Şenlik gününde sunum yapan öğrenciler, katılımcı arkadaşlarının genel kimya bilgilerini artırıcı, ilgilerini çekici görseller sunmaya dikkat etmişlerdir. Sunum yapan öğrenciler Cabir Bin Hayyan, petrolün damıtılması, suyun arıtılması, temiz enerji kaynakları, enerjide tasarruf yöntemleri, bazı element ve bileşiklerin molekül geometrileri, güvenlik sembolleri içeren maketlerle katılımcı arkadaşlarını bilgilendirmişlerdir. Ayrıca kimyanın tarihi çalışmasıyla kimyanın geçmişten günümüze gelişimi gösterilmiştir. Periyodik bulmaca sayesinde de öğrencilerin kimya dersi genel kavramlarını hatırlamaları sağlanmıştır. Sunum yapan öğrenciler yaptıkları deneylerle katılımcı arkadaşlarını bilgilendirmeye, dikkatlerini çekmeye ve eğlenerek öğrenmelerine çalışmışlardır. Bilim şenliğinde 
Jölenin Yapımı, Yanmayan Para, Katalizörün Hıza Etkisi, Sabun Yapımı, Yanardağdaki Kimyasal, Su Altında Alev, Beyaz Işı1k, Sodyumun Patlaması, İki Beyaz Bir Sarı, Saf Su Zehirli mi?, "Sıcak Yüzeye Dökülen Su Neden Hızlı Hareket Eder?”, "Açıta Bırakılan Ekmek Taş Kesilir de Neden Bisküvi Yumuşar?” ve "Kapalı Ortamlarda Hava Neden Boğucudur?” deneyleri yapılmıştır.

Bilim şenliğine katılımcı olarak katılan 9. ve 10. Sınıf öğrencilerine çalışma öncesi FDYTÖ ön test ve son test olarak uygulanmış ve toplanan veriler betimsel analiz yapılarak sonuçlar kaydedilmiştir.

Bilim şenliğinde aktif görev alan öğrencilerin proje ödevleri hakkındaki görüşlerini incelemek amacıyla PÖYTÖ çalışma sonrasında uygulanmış ve toplanan veriler betimsel analiz yapılarak raporlaştırılmıştır.

\section{Bulgular}

Araştırmada 9. ve 10. sınıfta öğrenim gören toplam 256 öğrenci üzerinde uygulanan verileri betimsel analiz edilmiş ve sonuçların genel görünümü Tablo 3 'te sunulmuştur.

Tablo 3. FDYTÖ Bulguların Genel Görünümü

\begin{tabular}{lccc}
\hline & $\begin{array}{c}\text { Katılan Öğrenci } \\
\text { Sayıs1 }\end{array}$ & $\begin{array}{c}\text { Öğrencilerde } \\
\text { yoklanan toplam } \\
\text { madde sayıs1 }\end{array}$ & $\begin{array}{c}\text { Olumlu yönde artış } \\
\text { gösteren ve olumlu } \\
\text { yönde devam eden } \\
\text { toplam madde sayıs1 }\end{array}$ \\
\hline 9. sinif & 121 & 1210 & 611 \\
\hline 10. sinif & 135 & 1350 & 771 \\
\hline
\end{tabular}

Tablo 4'te FDYTÖ'ne katılan 9. ve 10. sınıf öğrencilerinin ön test ve son testteki verilerinin betimsel analizi sonucu ön testteki düşüncesinde olumlu yönde artış gösteren ve olumlu yöndeki düşüncesi devam eden öğrenci sayıları verilmiştir. Ayrıca bu öğrencilerin ölçeğe tabi tutulan toplam öğrenci sayısı içerisindeki yüzdelik kısmı da belirtilmiştir.

Tablo 4. FDYTÖ Bulgularının Ayrıntılı Görünümü

\begin{tabular}{|c|c|c|c|}
\hline & $\begin{array}{l}\text { Artış Gösteren } \\
\text { Öğrenci Sayıs1 }\end{array}$ & $\begin{array}{c}\text { Olumlu } \\
\text { Düşüncesi } \\
\text { Devam Eden } \\
\text { Öğrenci } \\
\text { Say1s1 }\end{array}$ & $\begin{array}{c}\text { Artış Gösteren ve Olumlu } \\
\text { Düşüncesi Devam Eden } \\
\text { Öğrencilerin Yüzdelik } \\
\text { Kısmı }\end{array}$ \\
\hline Fen derslerine karşı özgüveninde & 66 & 75 & $\% 59,49$ \\
\hline Fen derslerine karş1 sevgisinde & 57 & 89 & $\% 61,60$ \\
\hline Fen derslerinin ilgi çekici içerikte olduğunu görmede & 73 & 65 & $\% 58,22$ \\
\hline $\begin{array}{l}\text { Fen derslerindeki bilimsel kısas ve soruları anlamaya } \\
\text { başlamada }\end{array}$ & 59 & 58 & $\% 49,36$ \\
\hline Fen derslerini tanıma bilgisinde & 89 & 54 & $\% 60,33$ \\
\hline Fen derslerinde başarılı olacağına dair inancında & 57 & 76 & $\% 56,11$ \\
\hline Fen derslerinde yeteneğinin arttı̆̆ına dair inancında & 70 & 70 & $\% 59,07$ \\
\hline Fen derslerinin eğlenceli olduğunu düşünmede & 98 & 54 & $\% 64,13$ \\
\hline $\begin{array}{lll}\text { Fen } & \text { derslerinde bilgiyi } & \text { arkadaşlarından } \\
\text { öğrenebileceğini düşünmede } & \\
\end{array}$ & 72 & 43 & $\% 48,52$ \\
\hline Fen derslerine karşı korkularının azaldığını düşünmede & 67 & 31 & $\% 41,35$ \\
\hline Fen derslerine karşı özgüveninde & 66 & 75 & $\% 59,49$ \\
\hline Fen derslerine karşı sevgisinde & 57 & 89 & $\% 61,60$ \\
\hline Fen derslerinin ilgi çekici içerikte olduğunu görmede & 73 & 65 & $\% 58,22$ \\
\hline
\end{tabular}

Tablo 4'e bakıldığında olumlu yönde en büyük orana sahip \%64,13 ile fen derslerini eğlenceli olduğunu düşünen öğrencilerin sayısının olduğu görülmektedir. Daha sonra \%61,60 ile fen derslerine yönelik sevgiye olumlu yönde cevap veren öğrenciler gelmektedir.

Tablo 5'te Proje Ödevlerine Yönelik Tutum Ölçeğine katılan öğrencilerin görüşlerinin genel görünümü araştırmaya katılan öğrenci sayısı, öğrencilerde yoklanan toplam madde sayısı ve bu maddelerde öğrencilerde olumlu yönde yanıt veren öğrenci sayısı ile birlikte verilmiştir. 
Tablo 5. PÖYTÖ Bulguları Genel Görünümü

\begin{tabular}{llc}
\hline Katılan öğrenci sayısı & $\begin{array}{l}\text { Öğrencilerde } \\
\text { yoklanan toplam } \\
\text { madde sayısı }\end{array}$ & $\begin{array}{l}\text { Proje Ödevleriyle İlgili Olumlu } \\
\text { Yönde Cevaplanan Madde Sayısı }\end{array}$ \\
\hline 27 & 270 & 249 \\
\hline
\end{tabular}

Tablo 6'da PÖYTÖ'ne katılan öğrencilerin görüşlerinin ayrıntılı sonuçları verilmiştir.

Tablo 6. PÖYTÖ Bulguları Genel Görünümü

\begin{tabular}{|c|c|c|c|c|c|c|}
\hline & & 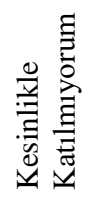 & 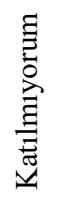 & 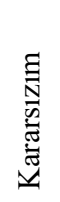 & 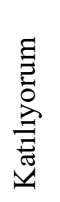 & 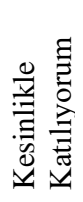 \\
\hline Proje ödevimin bilim şenliği şeklinde verilmesini faydalı buluyorum. & $\mathrm{f}$ & 0 & 0 & 2 & 3 & 22 \\
\hline Proje ödevimin bilim şenliği şeklinde verilmesi eğlenceliydi. & $\mathrm{f}$ & 1 & 0 & 1 & 5 & 20 \\
\hline Bilim şenliği sayesinde öğrendiklerimi deneysel olarak da görme imkânı buldum. & $\mathrm{f}$ & 0 & 0 & 0 & 2 & 25 \\
\hline $\begin{array}{l}\text { Fen derslerinin dışındaki derslerde de proje ödevlerinin bilim şenliği şeklinde } \\
\text { olmasının faydalı olacağını düşünüyorum. }\end{array}$ & f & 1 & 0 & 4 & 9 & 13 \\
\hline $\begin{array}{l}\text { Bilim şenliğinin önceki yıllardaki proje ödevlerine göre çok zamanımı aldığını } \\
\text { düşünüyorum. }\end{array}$ & $\mathrm{f}$ & 11 & 9 & 4 & 2 & 1 \\
\hline Bilim şenliği sayesinde arkadaşlarımla takım çalışması yapma imkânı buldum. & $\mathrm{f}$ & 0 & 0 & 0 & 3 & 24 \\
\hline Bilim şenliği sayesinde yeni arkadaşlar edinme imkânı buldum. & $\mathrm{f}$ & 4 & 0 & 3 & 6 & 14 \\
\hline Bilim şenliği çalışmasında tekrar görev almak isterim. & $\mathrm{f}$ & 1 & 0 & 1 & 3 & 22 \\
\hline $\begin{array}{l}\text { Bilim şenliği sayesinde kendimi ifade etme gücüne sahip olduğumun farkına } \\
\text { vardım. }\end{array}$ & f & 0 & 0 & 4 & 2 & 21 \\
\hline Sunduğum çalışmaların dışında arkadaşlarımın çalışmaları da dikkatimi çekti. & $\mathrm{f}$ & 2 & 1 & 0 & 2 & 22 \\
\hline Gelecek yıl da proje ödevi alarak bilim şenliğinde görev almak isterim. & $\mathrm{f}$ & 1 & 0 & 1 & 3 & 22 \\
\hline
\end{tabular}

Tablo 6'da ise PÖYTÖ'ne katılan öğrencilerin görüşlerinin ayrıntılı sonuçları verilmiştir. Tablo 6'daki sonuçlara göre öğrencilerin takım çalışması yapma imkânı bulma ve öğrendiklerini deneysel olarak da görme ile ilgili maddelere 'Katılıyorum' veya 'Kesinlikle Katıliyorum' seçeneklerinden birini seçerek tamamının olumlu yanıt vermiştir. Diğer maddelerde de bu olumlu etkinin öğrencinin bilim şenliğini faydalı bulması, eğlenceli bulması, bilim şenliğinde tekrar görev almak istemesi, günlük hayattaki birçok problemin nasıl çözüldügünü görmesi, bir probleme çözüm bulma imkânını yakalaması, bilim okuryazarlığı yönünden kendisinin geliştirdiğini düşünmesi maddelerinde \%90'ın üzerinde sonuçlar alınarak devam ettiği görülmüştür. En düşük yüzdeye sahip maddenin ise \%66,4 ile öğrencilerin proje ödevini dosya şeklinde hazırlamayı istemediklerine dair maddedir. Bunun dışındaki diğer tüm maddelerde \%70'in üzerinde olumlu sonuçlar alınmıştır.

\section{Tartışma ve Sonuç}

Bilim şenliklerinin öğrencilerin özelde kimya genelde fen (fizik, kimya biyoloji) derslerine yönelik tutumlarına olumlu yönde etki gösterdiği görülmüştür. Çalışmada bilim şenlikleri sayesinde fen derslerine yönelik özgüvenlerinin artırdığı görülmüştür. Özgüvenin artmasıyla öğrencilerin fen derslerinde başarılı olması, öğrenme ortamlarına aktif katılması ve ilgi duyduğu mesleğe yönelmesi sağlanabilir (George, 2006; Philipps, 2010). Fen derslerinin eğlenceli yönünü gören öğrenciler çalışmalarında öğrendiklerini uygulama imkânı bularak farklı bir öğrenme ortamı yakalamışlardır (Nolin, Bragesjö, \& Kasperowski, 2006). Bu sayede öğrencilerin öğrenmelerinde engel oluşturan soyut kavramlara somutlaştırma imkânı getirilmiş olacaktır (Bunderson \& Anderson, 1996).

Bilim şenliğindeki görseller, deneyler ve maketler gibi somutlaştırıcı ve dikkat çekici materyaller kullanılmasıyla birlikte bilgiyi arkadaşından öğrenme imkânı, öğrencilerin fen derslerindeki korkularının azalmasında etkili olmuştur. Bilim şenlikleri sayesinde fen derslerinin ilgi çekici içeriğini tanıma imkânı bulunduğuna yönelik sonuçların görülmesi, öğrencilerin bilimsel açıklamaları anlayabilmelerine olan inançlarının artmasına, bilimsel çalışma yayımlama ve paylaşma gelişimlerine katkı sağlayacaktır (Perry, 1995). 
Uygulama sırasında öğrenciler üzerinde yapılan gözlemlerde öğrencinin deneyi izlerken hangi konuyla alakalı olduğuna dair tahmin yaparak öğretmenine sorması ve bu tahminlerinde başarılı olması, öğrencilerin fen derslerinde başarılı olacaklarına dair inançlarının artmasında etkili olduğu düşünülmektedir. Bilimin eğlenceli yönünü gören öğrenciler bilimsel olaylardaki eleştirel yönlerini daha iyi kullanacaklardır (Bunderson \& Anderson, 1996; Albernathy \& Vineyard, 2001; Gomez, 2007).

Araştırmada bilim şenliklerinin olumlu sonuçlarının yanında olumsuz sonuçları da gözlemlenmiştir. $\mathrm{Bu}$ duruma öğrencilerin fen derslerine yönelik geçmiş korkuları ile üst sınıf ögrencilerinin alan derslerine yönelik olumsuz düşüncelerinden etkilenmelerinin sebep olduğu tahmin edilmektedir. $\mathrm{Bu}$ durumun öğrencilerin gelecek yaşantılarındaki kararlarına etki edebileceği de bilinmektedir (Seferoğlu, 2004). Ayrıca öğrencilerin bu kadar bilimsel bilgi ve terimlerin kullanıldığı bilim şenliğinde başaramayacağına dair kaygıları oluşmuş olabileceği düşünülmektedir. Sunum alanının kısıtlı olması öğrencilerin düşüncelerini olumsuz etkilemiş olabilir. Bilimsel terimlerin çok kullanılması da öğrencileri sıkmış ve fen derslerinin zor olduğu düşüncesini benimsemesine neden olmuş olabilir.

Elde edilen sonuçlar incelendiğinde bilim şenliği ile fen derslerine yönelik amaçlanan hedeflere ulaşma açısından tatmin edici sonuçlar elde edilmiştir. Bilim şenlikleri öğrencilere fen derslerinin başarılamayacak zor dersler olmadığını göstermiş, fen derslerine karşı önyargıları kırmış, fen derslerine karşı korkularını azaltmış, özgüvenlerini artırmış ve öğrencilerde fen derslerini başarırım düşüncesi hâkim olmuştur.

Bilim şenliklerinin öğrencilerin proje ödevlerine yönelik tutumlarına olumlu yönde etkisi görülmüştür. Araştırmada tek maddede \%66,4'lük olumlu sonuç dışındaki tüm maddelerde \%70'in üzerinde olumlu sonuçların alınması proje ödevlerinin etkin bir şekilde kullanılmasında bilim şenliklerinin olumlu bir etkisinin olduğunu göstermiştir. Öğrenciler proje ödevlerini bilim şenliklerinde aktif görev alarak çalışmalarını sunmayı hem eğlenceli hem de faydalı bulmakta, böyle çalışmalarda takım çalışması yapmaya olumlu bakmaktadırlar. Bu çalışmalar öğrencilerin bilime yönelik ilgilerinin artması, çalışmayı tasarlama sunma, bilgiyi paylaşma gelişimlerinin artmasına katkı sağlamaktadır (Perry, 1995). Öğrencilerin bu tür çalışmalarda tekrar görev almak istemesi de bilim şenliklerinin ileriki yıllarda tekrar uygulanmasının ne kadar önemli olduğunu göstermektedir. Öğrenci bir dosya hazırlayarak bunu getirip öğretmenine teslim etmeyi yeğlememekte, aktif olarak bilim şenliklerinde görev almayı istemektedir (Korkmaz, 2004). Dosya şeklinde hazırlanarak verilen proje ödevlerine harcanan zamana göre bilim şenliklerinin çok zaman almadığını düşünen öğrencilerin aslında bilim şenliklerinde daha fazla zaman harcamış olmalarına rağmen çalışmayı ne kadar sevdikleri, ne kadar faydalı buldukları bu sayede severek zaman ayırdıkları düşünülmektedir. Bu da ögrencilerin bilim şenliğindeki olumlu tutum çıktılarından biridir (Yıldırım \& Şensoy, 2016). Öğrencilerin kendilerini ifade etme imkânı bulduğu bilim şenliklerinin sosyal yaşamda veya eğitim ortamında kendisini ifade etme sıkıntısı yaşayan öğrencilere de faydalı olduğu elde edilen sonuçlarla desteklenmektedir. Ayrıca öğrencilerin günlük hayatta karşılaştıkları bir probleme nasıl çözüm bulunduğunu görmesi, probleme çözüm bulma imkânı yaşaması ve bilim okuryazarlığının geliştiğini düşünmesi ülkemizde bilim kuruluşlarınca da desteklenmiştir (Tübitak Proje Rehberi, 2012). Sonuçlar göstermektedir ki proje ödevi alan öğrencilerin çalışmalarını bilim şenliğinde aktif görev alarak sunmaları proje ödevlerinin etkinliğinin artmasına katkı sağlamaktadır.

\section{Öneriler}

- Bilim şenliklerinin yapılma sıklığının artırılması, öğrencinin fen bilimleri derslerine olan ilgisinin artmasını sağlayacaktır. Bu amaçla okullarda bu tür çalışmalara ağırlık verilmesi önem arz etmektedir.

- Proje ödevlerinde bilim şenliği çalışmalarında yer verilmesi öğrencilerin proje ödevlerinde etkin rol almasını sağlayacaktır.

- Fen laboratuvarlarının daha etkili materyallerle donatılıp, fen bilimi derslerinin laboratuvar ortamında işlenmesi derslerin daha verimli hale gelmesine yardımcı olacaktır. Böylece öğrencilerin derse olan ilgisi de artacaktır. 
- Öğretmenlerin derslerde sunuş stratejisinden ziyade buluş ve araştırma-inceleme stratejilerini kullanmaları öğrencinin bilimsel süreç basamaklarını öğrenmesinde yardımcı olacak ve bilgiyi keşfetme yoluyla öğrenen öğrenci bilgiyi içselleştirecektir.

- Bilim şenlikleri çalışmalarının öğrencilerin akranlarından daha iyi öğrenmesine katkıda sağlayacağı ve öğretmenine soramayacağı soruları bile akranına soran öğrencinin dersi kavramasının daha kolay olacağı düşünülmektedir.

- Öğrencilerin fen derslerine olan ilgisinin artması, ders öğretmenlerinin görsel materyal, deney ve maket gibi somutlaştırıcı ve dikkat çekici materyalleri kullanmasında etkili olacağı öngörülmektedir.

- Özellikle her okulda bilim günleri ve/veya bilim şenliği düzenlenmesi ülke genelinde bu kültürünün oluşmasını ve öğrencilerin fen bilimlerini daha yakından tanımalarını ve sevmelerini sağlayabilir.

- Okullarda fen derslerine olan ilgiyi artırmak için tanıtım günleri yapılabilir. ücret verilebilir.

- Öğretmenlere bilim şenlikleri ile ilgili bilgilendirmeler yapılabileceği gibi teşvik amaçlı

- Öğrencilere proje ödevlerinin bilim şenliği şeklinde verilmesi öğrencilerin bilimsel süreç basamaklarını kullanarak bir ürün ortaya koyma ve sunma becerilerini geliştirebilir. 


\section{Kaynakça}

Aladağ, S. (2005). İlköğretim matematik ögretiminde proje tabanl öğrenme yaklaşımının öğrencilerin akademik başarısına ve tutumuna etkisi (Yayınlanmamış Yüksek Lisans Tezi). Ankara: Gazi Üniversitesi.

Aydın, A. (2007). Eğitim psikolojisi. Ankara: Tek Ağaç Eylül Yayıncılık.

Bacanak, A., Karamustafaoğlu, O., \& Köse, S. (2003). Yeni bir bakış: Eğitimde teknoloji okuryazarlığı. Pamukkale Üniversitesi Eğitim Fakültesi Dergisi, 2(14), 191-196.

Barker, V., \& Millar, R. (2000). Students' reasoning about basic chemical thermodynamics and chemical bonding: what changes occur during a context-based post-16 chemistry course International Journal of Science Education, 22(11), 1171-1200.

Bozdemir, E. (2018). Tubitak bilim fuarlarinda yapilan projelerin öğrencilerüzerinde etkililiğinin değerlendirilmesi (Yayınlanmamış Yüksek Lisans Tezi). Çanakkale: Çanakkale Onsekiz Mart Üniversitesi.

Bozkurt, S., Aslanargun, E., Akın, S., \& Kılıç, A. (2014). İköğretimde uygulanan proje ve performans ödevlerine ilişkin sınıf öğretmenlerinin görüşleri. Pamukkale Üniversitesi Sosyal Bilimler Enstitüsü Dergisi, 18, 157-173.

Bunderson, E. D., \& Anderson, T. (1996). Preservice elementary teachers' attitudes toward their past experience with science fairs. School Science And Mathematics, 96(7), 371-377.

Camcı, S. (2008, Ankara). Bilim şenliğine katılan ve katılmayan ögrencilerin bilim ve bilim insanlarına yönelik ilgi ve imajlarının karşılaştırılması (Yayımlanmamış Yüksek Lisans Tezi). Ankara:Hacettepe Üniversitesi Sosyal Bilimler Enstitüsü.

Çiçek, Ş. (2008). Lise 2 Öğrencilerinin Kimya dersinde başarilari ve tutumlari üzerine bilim şenliklerinin etkisinin incelenmesi (Yayımlanmamış Yüksek Lisans Tezi). Ankara: Gazi Üniversitesi.

Çı̆̆rık, E. (2016). Bilim merkezlerinde yürütülen öğrenme etkinliklerinin ögrrencilerin fen bilimleri dersindeki akademik başarilarina ve tutumlarına etkisi (Yayımlanmamış Doktora Tezi). Bursa: Uludağ Üniversitesi.

Demirel, Ö. (1999). Öğretmen el kitabı. Ankara: Pegem Yayıncılık.

Fidan, N. (1996). Okulda öğrenme ve öğretme. Ankara: Kadığlu Matbaası.

George, R. (2006). A Cross-domain analysis of change in students' attitudes toward science and attitudes about the utility of science. International Journal of Science Education, 28(6), 571589.

Karadeniz, O., \& Ata, B. (2013). Soyal bilgiler dersinde proje fuarının kullanılmasına ilişkin öğrenci görüşleri. Adlyaman Üniversitesi Sosyal Bilimler Enstitüsü Dergisi, 6(14), 375-410.

Keçeci, G., Kırbağ Zengin, F., \& Alan, B. (2017). Bilim şenliği tutum ölçeği: geçerlilik ve güvenirlik çalışması. ÇaInternational Journal Of Eurasia Social Sciences, 8(27), 562-575.

Knapp, D. (2000). Memorable experince of a science field trip. School Science and Mathematics, 100(2), 65-72.

Korkmaz, H. (2004). The images of the scientist through the eyes of the Turkish children. P. S. Conference (Dü.). Canyon, Texas, USA.

Kütükte, Z. (2010). İlkögretim ögrretmenlerinin performans ve proje ödevlerine ilişkin algl, görüş ve uygulama durumları (Yayımlanmamış Yüksek Lisans Tezi). Tokat: Gaziosmanpaşa Üniversitesi.

MEB. (2018). Ortä̈ğretim kimya dersi (9, 10, 11 ve 12. sinıflar) ögretim programı. Ankara: TTKB (T.C. Milli Eğitim Bakanlığı Talim ve Terbiye Kurulu Başkanlığı). 
Nolin, J., Bragesjö, F., \& Kasperowski, D. (2006). OPUS, Optimising public understanding of science and technology [en linea]. http://www. univie. ac. at/virusss/opus/mpapers. html. adresinden alınmıştır.

Perry, P. J. (1995). Getting started in science fairs: From planning to judging.

Philipps, M. (2010). Research Trends and Findings From a Decade (1997-2007) of Research on Informal Science Education and Free-Choice Science Learning. 13(1), 3-22.

Seferoğlu, S. (2004). Öğretmen adaylarının öğretmenliğe yönelik tutumlart. XII. Ulusual Eğitim Bilimleri Kongresi Bildirileri, (ss. 413-425). Ankara.

Şahin, Ş. (2012). Bilim şenliklerinin 10. sınıf öğrencilerinin kimya dersine yönelik tutumlarına olan etkisi. Uşak Üniversitesi Sosyal Bilimler Dergisi, 5(1), 89-103.

Tezcan, S., \& Gülperçin, N. (2008). İzmir'de bilim fuarı ve eğitim bilim şenliği katılımcılarının böceklere bakış1. Türkiye Entomoloji Dergisi, 32(2), 103-113.

The Physical Sciences Initiative. (1991). Social and applied aspects what is meant by "social and applied”? www.psi-net.org/chemistry/s1/socialandapplied.pdf adresinden alınmıştır.

Tübitak Proje Rehberi. (2012). 4006 tübitak bilim fuarları destekleme programı.

Yalın, H. İ. (2003). Öğretim teknolojileri ve materyal geliştirme. Ankara: Nobel Yayın Dağıtım.

Yavuz, S., Büyükekşi, C., \& Büyükekşi, S. I. (2014). bilim şenliğinin bilimsel inanışlar üzerine etkisi. S. Karaelmas Journal of Educational Sciences 2, 168-174.

Yıldırım, H. İ. (2018). Bilim şenliklerinin ortaokul 6. sınıf öğrencilerinin problem çözme becerilerine etkisi. Trakya Üniversitesi Eğitim Fakültesi Dergisi, 8(2), 390-409.

Yıldırım, H. İ., \& Şensoy, Ö. (2016). Bilim şenliklerinin 6. sınıf öğrencilerinin fen bilimleri dersine yönelik tutumlarına etkisi. Türk Eğitim Bilimleri Dergisi, 14(1), 23-40.

Young, T. E. (2000, March/April). Science fair projects bring it all together. Book Report. 6-8. 